\title{
Ice hockey lung - a case of mass nitrogen dioxide poisoning in the Czech Republic
}

\author{
Kristian Brat MD¹, Zdenek Merta MD PhD ${ }^{1}$, Marek Plutinsky MD¹, Jana Skrickova MD PhD , Miroslav Stanek Ing²
}

\begin{abstract}
K Brat, Z Merta, M Plutinsky, J Skrickova, M Stanek. Ice hockey lung - a case of mass nitrogen dioxide poisoning in the $\mathrm{Czech}$ Republic. Can Respir J 2013;20(6):e100-e103.

Nitrogen dioxide $\left(\mathrm{NO}_{2}\right)$ is a toxic gas, a product of combustion in malfunctioning ice-resurfacing machines. $\mathrm{NO}_{2}$ poisoning is rare but potentially lethal. The authors report a case of mass $\mathrm{NO}_{2}$ poisoning involving 15 amateur ice hockey players in the Czech Republic. All players were treated in the Department of Respiratory Diseases at Brno University Hospital in November 2010 - three as inpatients because they developed pneumonitis. All patients were followed-up until November 2011. Complete recovery in all but one patient was achieved by December 2010. None of the 15 patients developed asthma-like disease or chronic cough. Corticosteroids appeared to be useful in treatment. Electric-powered ice-resurfacing machines are preferable in indoor ice skating arenas.
\end{abstract}

Key Words: Ice hockey; Ice resurfacing machine; Nitrogen dioxide; Poisoning
Learning Objectives

- To recognize that asthma-like disease or chronic cough may develop after acute nitrogen dioxide $\left(\mathrm{NO}_{2}\right)$ poisoning.

- Environmental assessment service inquiry should be performed if $\mathrm{NO}_{2}$ poisoning is suspected.

Pretest

- What essential conditions cause 'ice hockey lung'?

- Can $\mathrm{NO}_{2}$ poisoning be life-threatening?

\section{CASE PRESENTATION}

On November 23, 2010, an amateur ice hockey tournament was held in an indoor ice-skating arena in Brno, Czech Republic. Fifteen of the 20 players developed multiple respiratory symptoms within $48 \mathrm{~h}$ following the tournament. Initially, the cause of their problem was not clear; however, identical history and similar symptoms suggested possible mass poisoning. The Poison Control Centre in Prague was, therefore, consulted. Twelve of the 15 patients were treated as outpatients. Three players developed respiratory failure and had to be treated as inpatients in the Department of Respiratory Diseases, Brno University Hospital between November 24 and 28. Cough, dyspnea, chest pain and hemoptysis were the primary symptoms. The local Environmental Assessment Service (the Czech counterpart of Occupational Health and Safety in the United States) provided measurements of carbon monoxide $(\mathrm{CO})$ and $\mathrm{NO}_{2}$ levels in the ice skating arena. According to current emission standards, required by Czech environmental legislation, the $1 \mathrm{~h}$ time-weighted average concentration limits are $5 \mathrm{mg} / \mathrm{m}^{3}$ for $\mathrm{CO}$ and $100 \mu \mathrm{g} / \mathrm{m}^{3}$ for $\mathrm{NO}_{2}$ (Appendix). These limits were exceeded for both $\mathrm{CO}$ and $\mathrm{NO}_{2}$ (1.95 times for $\mathrm{CO}$; more than 10 times for $\mathrm{NO}_{2}$ ). Ventilation in the arena was determined to be insufficient, leading to the accumulation of products of incomplete combustion due to engine malfunction in the resurfacing machine. The diagnosis of 'ice hockey lung' was thus confirmed.

\section{Des poumons de hockeyeurs : un cas d'empoisonnement massif au dioxyde d'azote en République tchèque}

Le dioxyde d'azote $\left(\mathrm{NO}_{2}\right)$, un gaz toxique, est un produit de combustion des surfaceuses défectueuses. Bien qu'il soit rare, l'empoisonnement au $\mathrm{NO}_{2}$ peut être fatal. Les auteurs rendent compte d'un cas d'empoisonnement massif au $\mathrm{NO}_{2}$ chez 15 joueurs de hockey amateurs de la République tchèque. En novembre 2010, tous les joueurs ont été traités au département des maladies respiratoires de l'hôpital universitaire de Brno, et trois d'entre eux ont été hospitalisés en raison d'une pneumonite. Tous les patients ont été suivis jusqu'en novembre 2011. En décembre 2010, ils s'étaient tous totalement rétablis, sauf un. Aucun des 15 patients n'a présenté de maladie de type asthmatique ou de toux chronique. Les corticoïdes semblaient constituer un traitement utile. Les surfaceuses électriques sont préférables dans les arénas intérieures.

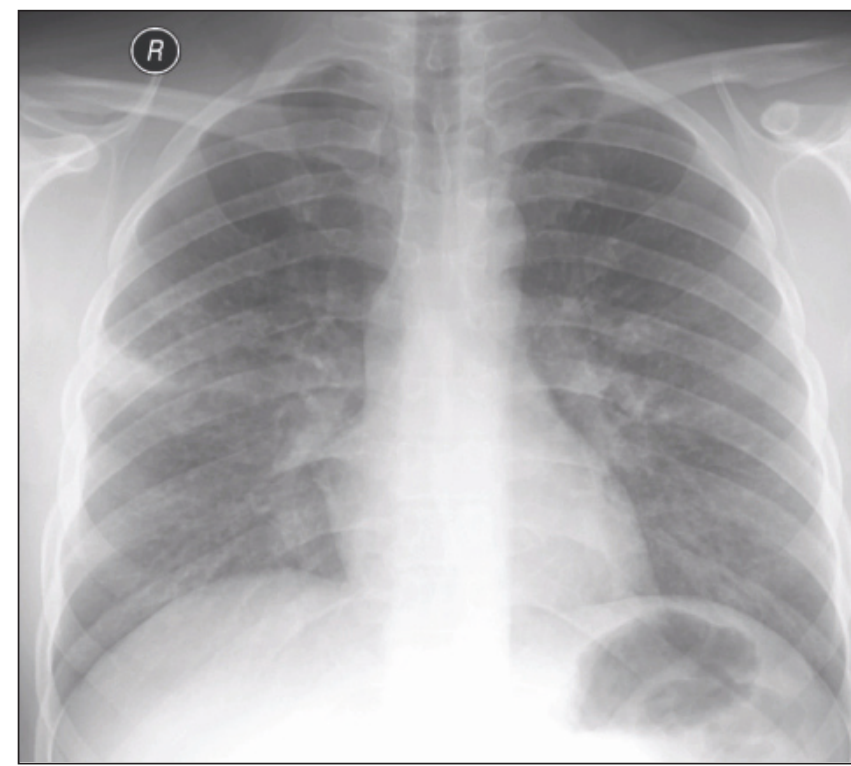

Figure 1) Chest $x$-ray showing right-sided infiltration

A chest $\mathrm{x}$-ray (CXR) was performed in all 15 patients; a pathological finding was present in five, predominantly a right-sided infiltration (Figure 1). A computed tomography (CT) scan in one patient revealed peribronchovascular interstitial pattern intensification, predominantly in the middle lobe and lingula (Figure 2). This patient exhibited the most pronounced CXR finding and the most severe respiratory failure. The distribution of symptoms among the 15 patients is shown in Figure 3.

Laboratory data showed elevated carboxyhemoglobin levels in four patients and elevated bilirubin levels in two. Lung function tests showed restrictive ventilatory disorder in four patients $(26.6 \%)$,

\footnotetext{
${ }^{1}$ Department of Respiratory Diseases, University Hospital; ${ }^{2}$ Regional Environmental Assessment Service, Brno, Czech Republic

Correspondence: Dr Kristian Brat, Department of Respiratory Diseases, University Hospital, Jihlavska 20, Brno 62500, Czech Republic.

Telephone 42-053-223-2018, e-mail kristian.brat@seznam.cz
} 


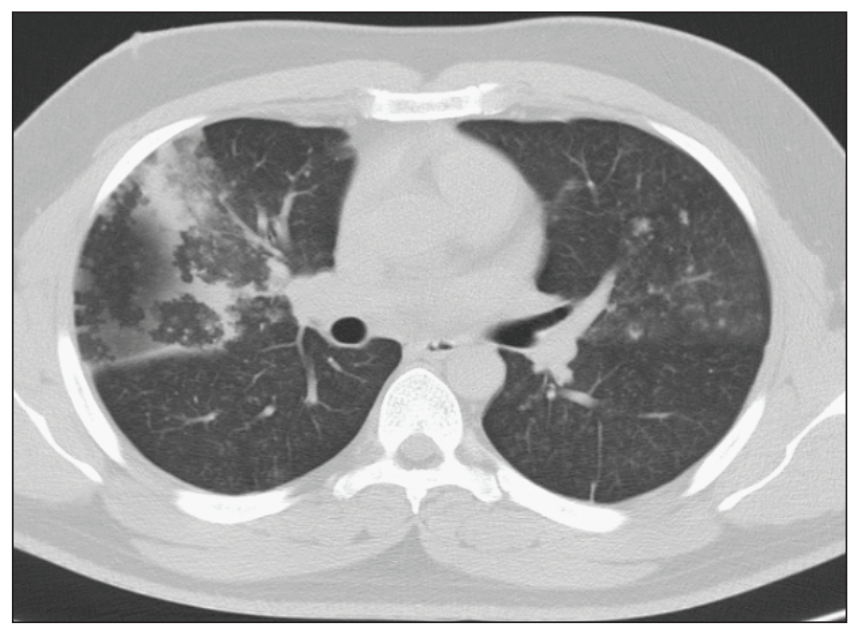

Figure 2) Computed tomography scan showing peribronchovascular interstitial pattern intensification

obstructive disorder in one $(6.7 \%)$ and combined disorder in one (6.7\%). Hypoxemia was present in four patients (26.6\%), ranging from $6.9 \mathrm{kPa}$ to $9.8 \mathrm{kPa}(52.0 \mathrm{mmHg}$ to $73.5 \mathrm{mmHg})$. None of the patients showed a decrease in $\mathrm{CO}$ diffusion. Fraction of exhaled nitric oxide (FeNO) was elevated in five of nine patients, with values of 15 parts per billion (ppb) to $44 \mathrm{ppb}$, median $26 \mathrm{ppb}$ (cut-off value $25 \mathrm{ppb}$ ) (Table 1). To the authors' knowledge, the present article represents the first ever published report of FeNO testing in a case of $\mathrm{NO}_{2}$ poisoning.

Eight of the 15 patients were treated with intravenous or inhaled corticosteroids, sometimes combined with methylxanthines ( $\mathrm{n}=5$ [33.3\%]), beta $_{2}$-agonists $(n=5[33.3 \%])$ and antibiotics $(n=5[33.3 \%])$. Three

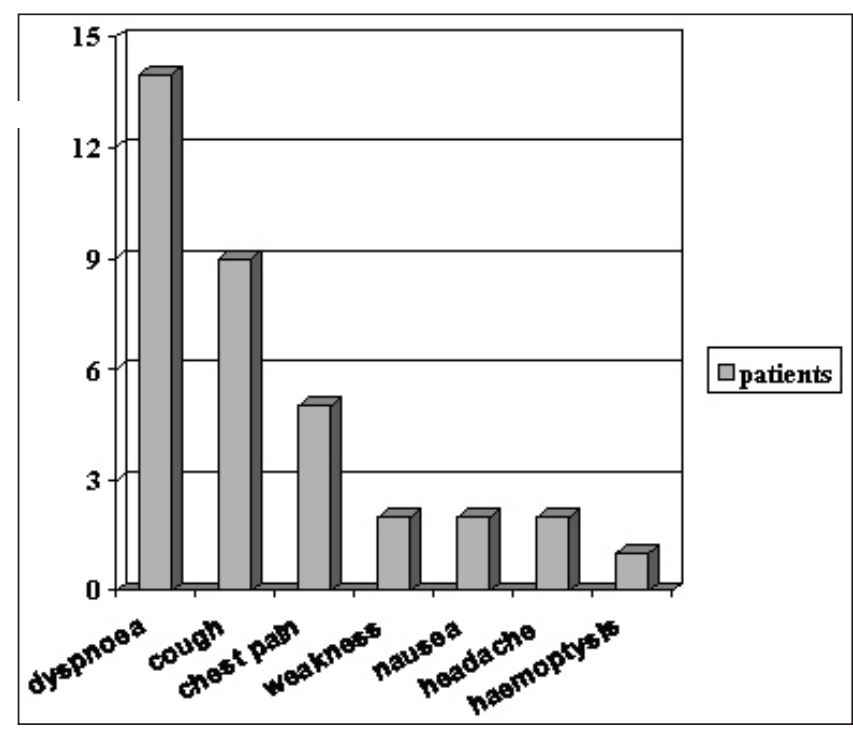

Figure 3) Frequency of symptoms. Total 15 patients

(20\%) patients underwent oxygen therapy. The treatment was successful in 14 patients and was discontinued at the end of December 2010. Elevated FeNO levels decreased in seven of nine patients (mean decrease $7.16 \mathrm{ppb}$ ). At hospital discharge, all patients demonstrated complete resolution of CXR findings. Only one patient continued inhaled corticosteroid treatment for an additional three months due to the persistence of a mild obstructive ventilatory disorder. By November 2011, none of the followed-up patients experienced pulmonary symptoms.

TABLE 1

Summary of laboratory data, imaging and lung function tests

\begin{tabular}{|c|c|c|c|c|c|c|c|c|c|}
\hline \multirow[b]{2}{*}{ Patient } & \multicolumn{4}{|c|}{ Laboratory data } & \multicolumn{2}{|c|}{ Imaging } & \multicolumn{3}{|c|}{ Lung function test } \\
\hline & CO-Hgb, \% & Met-Hgb, \% & $\mathrm{PaO}_{2}, \mathrm{kPa}$ & $\begin{array}{c}\text { Bilirubin, } \\
\mu \mathrm{mol} / \mathrm{L}\end{array}$ & Chest x-ray & CT scan & FeNO, ppb & $\begin{array}{l}\text { Ventilatory } \\
\text { disorder }\end{array}$ & $\begin{array}{c}\text { CO-diffusion, } \\
\mathrm{K}_{\mathrm{CO}} \%\end{array}$ \\
\hline 1 & NP & NP & $>9.9$ & NP & Normal & NP & 19 & None & 139 \\
\hline 3 & NP & NP & $>9.9$ & NP & Normal & NP & 20 & None & 124 \\
\hline 4 & 1.3 & 0.7 & $>9.9$ & 42.7 & $\begin{array}{l}\text { Right-sided } \\
\text { infiltration }\end{array}$ & NP & $\mathrm{N}$ & None & 101 \\
\hline 7 & 1.4 & 0.6 & $>9.9$ & NP & Normal & NP & 25 & None & 115 \\
\hline 8 & 1.6 & 0.7 & $>9.9$ & NP & Normal & NP & NP & Mild restrictive & 127 \\
\hline 9 & 1.4 & 0.9 & 9.8 & NP & $\begin{array}{l}\text { Right-sided } \\
\text { infiltration }\end{array}$ & NP & NP & None & 121 \\
\hline 13 & 1.3 & 0.9 & 8 & 8.6 & $\begin{array}{l}\text { Right-sided } \\
\text { infiltration }\end{array}$ & NP & 44 & None & 129 \\
\hline 14 & NP & NP & $>9.9$ & NP & Normal & NP & NP & $\begin{array}{l}\text { Severe } \\
\text { restrictive }\end{array}$ & NP \\
\hline 15 & 1.4 & 0.7 & $>9.9$ & NP & Normal & NP & 15 & Mild restrictive & NP \\
\hline Total tests performed, $\mathrm{n}$ & 10 & 10 & 15 & 3 & 15 & 1 & 9 & 15 & 12 \\
\hline $\begin{array}{l}\text { Pathological finding } \\
\text { present, \% of tests }\end{array}$ & 40 & 0 & 26.6 & 66.6 & 33.3 & 100 & 55.5 & 40 & 0 \\
\hline
\end{tabular}

Bolded values indicate pathological findings. Bilirubin cut-off value $17 \mu \mathrm{mol} / \mathrm{L} ; \mathrm{CO}-\mathrm{Hgb}$ Carboxyhemoglobin level in arterial blood, cut-off value 1.5\%; CT Computed tomography; FeNO Fraction of exhaled nitric oxide, cut-off value 25 parts per billion ( $p p b) ; K_{\text {co }}$ Carbon monoxide (CO)-diffusion transfer coefficient, cut-off value 80\%; Met-Hgb Methemoglobin level in arterial blood, cut-off value 1.0\%; NP Examination or test was not performed; PaO ${ }_{2}$ Partial pressure of oxygen level in arterial blood, cut-off value $9.9 \mathrm{kPa}$ 


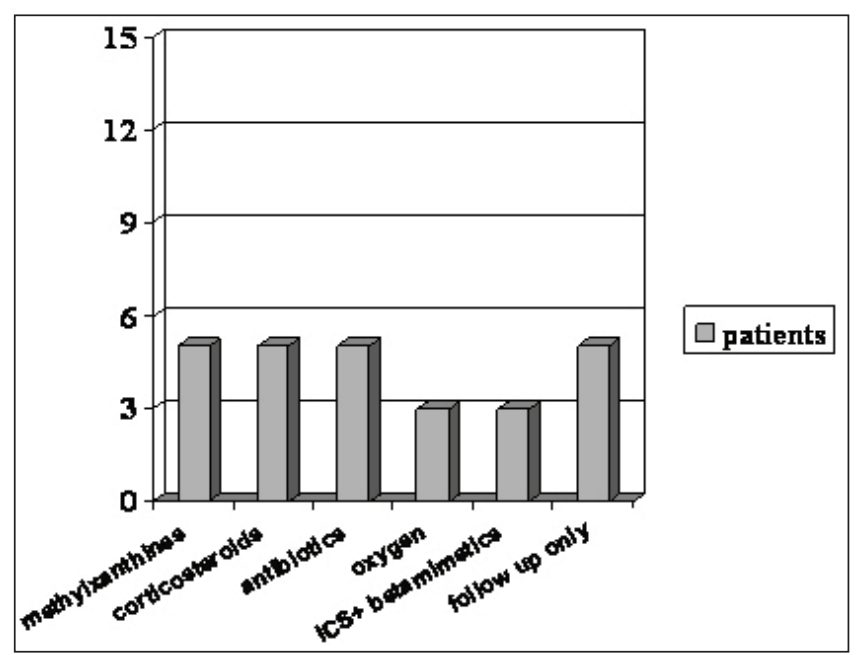

Figure 4) Frequency of treatment used in 15 patients. ICS Inhaled corticosteroids

In December 2010, the malfunctioning ice-resurfacing machine was replaced. All of the patients obtained free season tickets to the ice skating arena.

\section{DISCUSSION}

$\mathrm{NO}_{2}$ is a poorly soluble, toxic gas that easily penetrates the peripheral airways and alveoli, where it combines with water to produce nitrous and nitric acid. The presence of nitric acid increases cell membrane permeability, resulting in interstitial pulmonary edema and pneumonitis (1). $\mathrm{NO}_{2}$ is a combustion product of gasoline-, diesel-, and propanebutane-powered ice-resurfacing machines. An accumulation of $\mathrm{NO}_{2}$ may occur under certain conditions including malfunction of resurfacing machine engines and inadequate air ventilation (2,3). Exposure to high concentrations of $\mathrm{NO}_{2}$ in an insufficiently ventilated space (eg, an indoor ice skating arena) may result in damage to lung tissue and severe pneumonitis (3). The term 'ice hockey lung' was first coined in 1980s in North America in association with several cases of mass $\mathrm{NO}_{2}$ poisonings in indoor ice arenas. Other conditions due to acute exposure to high levels of $\mathrm{NO}_{2}$ include 'silo fillers disease', 'numismatist's pneumonitis' and fireworkers' $\mathrm{NO}_{2}$ poisoning $(4,5)$. On the other hand, chronic exposure to lower levels of $\mathrm{NO}_{2}$ may result in chronic cough, asthma-like disease or chronic bronchitis (6). Chronic cough and asthma-like disease may also develop after acute exposure $(7,8)$.

The most frequent clinical symptoms of acute $\mathrm{NO}_{2}$ poisoning are cough, chest pain, dyspnea, hemoptysis and cyanosis $(1-4,7)$. Weakness, headache or nausea may also be present. The symptoms usually develop within $6 \mathrm{~h}$ to $48 \mathrm{~h}$ following exposure depending on exposure time and $\mathrm{NO}_{2}$ levels in the arena. The severity of symptoms peaks $24 \mathrm{~h}$ to $72 \mathrm{~h}$ after exposure $(1,7)$. Medical history, physical examination, CXR and/ or CT scans, blood gas analysis and lung function tests contribute to the diagnosis. The diagnosis is confirmed when both malfunction of the engine of the ice-resurfacing machine (with incomplete fuel combustion) and the presence of excessive $\mathrm{NO}_{2}$ levels in the arena are substantiated. The symptoms of $\mathrm{NO}_{2}$ poisoning depend on the concentration and the duration of exposure, and vary from benign symptoms to severe respiratory failure with the need for invasive mechanical pulmonary ventilation and intensive care $(1,2)$.

Various treatment regimens have been reported. Because cases of $\mathrm{NO}_{2}$ poisoning are infrequent, there is no consensus regarding treatment. In most cases, the use of inhaled and/or intravenous corticosteroids has been reported. Corticosteroids may reduce symptoms, improve or restore lung function and prevent the development of asthma-like disease in a proportion of patients $(3,7,8)$. Although less regularly reported, different treatment regimens have been used to reduce symptoms, prevent infection and improve lung function. These include methylxanthines, beta 2 -agonists and antibiotics $(1,3,4,7)$. Short-term oxygen therapy is required for patients with respiratory failure. Invasive pulmonary ventilation and intensive care is necessary for patients with life-threatening respiratory failure.

Ice hockey is a popular sport in many countries, including the Czech Republic. Relatively scarce reports in the literature of $\mathrm{NO}_{2}$ and $\mathrm{CO}$ poisoning in ice skating arenas likely under-represent the problem. Environmental assessment service inquiry and measurements of $\mathrm{NO}_{2}$ and $\mathrm{CO}$ levels in ice arenas are essential when 'ice hockey lung' is suspected. A simple way to prevent $\mathrm{NO}_{2}$ and $\mathrm{CO}$ poisoning is the replacement of combustion-engine ice-resurfacing machines with electrically powered machines. Where gasoline-, diesel- or propanebutane-powered ice-resurfacing machines are in use, regular environmental assessment service controls should be performed.

In our case, we established the diagnosis within $36 \mathrm{~h}$ after exposure, and all 15 patients in the present report were treated in our department. All but one of the 15 patients experienced complete recovery by December 2010. Replacement of the malfunctioning iceresurfacing machine had been arranged in December 2010. None of the patients demonstrated clinical symptoms of asthma-like disease by November 2011. Increases in FeNO may indicate mechanisms of asthma-like inflammation in the bronchi. Because there was a good clinical response to corticosteroids, we consider corticosteroid therapy to be warranted in patients with severe lung function impairment and/ or respiratory failure. Precautions against exposure to $\mathrm{NO}_{2}$ and $\mathrm{CO}$ are strongly recommended including adequate ventilation in arenas, proper maintenance of engines and mandatory checks of resurfacing machine exhaust or replacement of combustion engines with electrically powered engines.

\section{Post-test}

- Which essential conditions cause 'ice hockey lung'?

At least two of the following three conditions must be present for $\mathrm{NO}_{2}$ poisoning to develop:

- A malfunctioning engine of a gasoline-, propane-butane- or diesel-powered ice resurfacing machine (with incomplete combustion leading to accumulation of $\mathrm{NO}_{2}$ );

- Poorly ventilated indoor ice arena; and

- Sufficient exposure.

- Can $\mathrm{NO}_{2}$ poisoning be life-threatening?

$\mathrm{NO}_{2}$ poisoning is rare but potentially lethal because it can lead to acute respiratory failure with pulmonary edema and the need for invasive pulmonary ventilation. Pulse oximetry, lung function tests and blood gas examination should be performed in each patient.

AUTHOR CONTRIBUTIONS: Kristian Brat MD - main author of the manuscript. Identified and managed the case. Zdenek Merta MD - coauthor of the manuscript. Interpreted the results of lung function tests. Marek Plutinsky MD - co-managed the case. Jana Skrickova, prof., MD supervised the case management and the paper. Miroslav Stanek - supervised the Environmental Assessment Service controls, provided the results of $\mathrm{NO}_{2}$ and $\mathrm{CO}$ measurements in the ice arena.

APPENDIX
Corresponding United States limits for $\mathrm{CO}$ and $\mathrm{NO}_{2}(9,10)$
The current Occupational Safety and Health Administration
(OSHA) permissible exposure limit for CO is 50 parts per million
(ppm) or $55 \mathrm{mg} / \mathrm{m}^{3}$ as an $8 \mathrm{~h}$ time-weighted average (TWA) con-
centration. The National Institute for Occupational Safety and
Health has established a recommended exposure limit for CO of
$35 \mathrm{ppm}$ or $40 \mathrm{mg} / \mathrm{m}^{3}$ as an $8 \mathrm{~h}$ TWA and 200 ppm or $229 \mathrm{mg} / \mathrm{m}^{3}$ as
a ceiling. The American Conference of Governmental Industrial
Hygienists has assigned CO a threshold limit value of $25 \mathrm{ppm}$ or
$29 \mathrm{mg} / \mathrm{m}^{3}$ as a TWA for a normal 8 h workday. OSHA Safety
Hazard Information Bulletin on Potential Carcinogenicity of Diesel
Exhaust: Limits for nitrogen dioxide: 5 ppm or $9 \mathrm{mg} / \mathrm{m}^{3}$ ceiling and
3 ppm or $6 \mathrm{mg} / \mathrm{m}^{3} 8 \mathrm{~h}$ TWA.




\section{REFERENCES}

1. Soparkar G, Mayers I, Edouard L, Hoepnner H: Toxic effects from nitrogen dioxide in ice-skating arenas. CMAJ 1993;148:1181-2.

2. Brauer M, Spengler JD. Nitrogen dioxide exposures inside ice skating rinks. Am J Public Health 1994;84:429-33.

3. Karlson-Stiber C, Hojer J, Sjoholm A, Bluhm G, Salmonson H. Nitrogen dioxide pneumonitis in ice hockey players.

J Intern Med 1996;239:451-6.

4. Sriskandan K, Pettingale KW. Numismatist's pneumonitis. A case of acute nitrogen dioxide poisoning. Postgraduate M J 1985;61:819-21.

5. Epler GR. Silo filler's disease: A new perspective. Mayo Clin Proc 1989;64:368-70.

6. Neas LM, Dockery DW, Ware JH, Spengler JD, Speizer FE, Ferris BG Jr. Association of indoor nitrogen dioxide with respiratory symptoms and pulmonary function in children.

Am J Epidemiol 1991;134:209-14.

7. Kahan ES, Martin UJ, Spungen S, Ciccolella D, Criner GJ.

Chronic cough and dyspnea in ice hockey players after an acute exposure to combustion products of a faulty ice resurfacer. Lung 2007; 185:47-54.

8. Rosenlund M, Jungnelius S, Bluhm G, Svartengren M. A 5-year follow-up of airway symptoms after nitrogen dioxide exposure in an indoor ice arena. Arch Environ Health 2004;59:213-7.

9. United States Department of Labor. Occupational Safety and Health Administration. Occupational Safety and Health Guideline for Carbon Monoxide. <www.osha.gov/SLTC/healthguidelines/ carbonmonoxide/recognition.html> (Accessed March 15, 2013).

10. United States Department of Labor. Occupational Safety and Health Administration. OSHA Safety Hazard Information Bulletin on Potential Carcinogenicity of Diesel Exhaust. <www.osha.gov/dts/hib/hib_data/hib19881130.html> (Accessed March 15, 2013). 


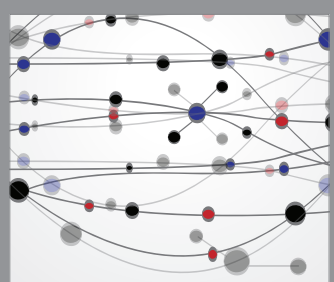

The Scientific World Journal
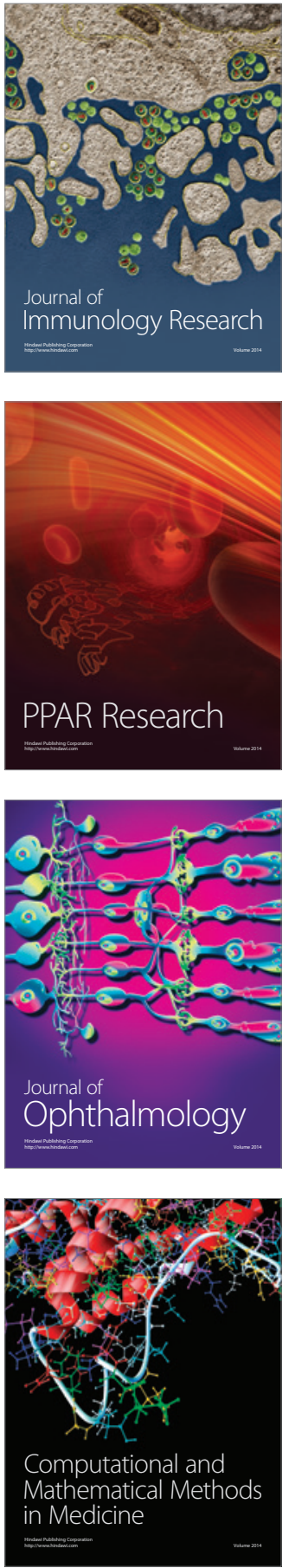

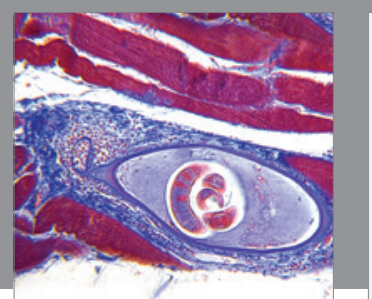

Gastroenterology Research and Practice

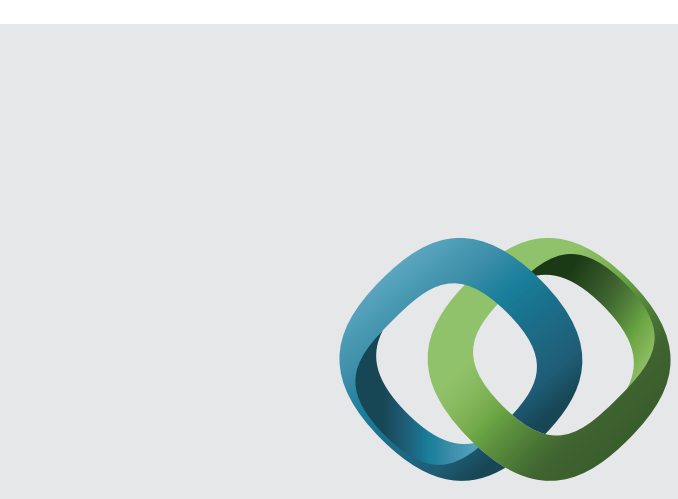

\section{Hindawi}

Submit your manuscripts at

http://www.hindawi.com
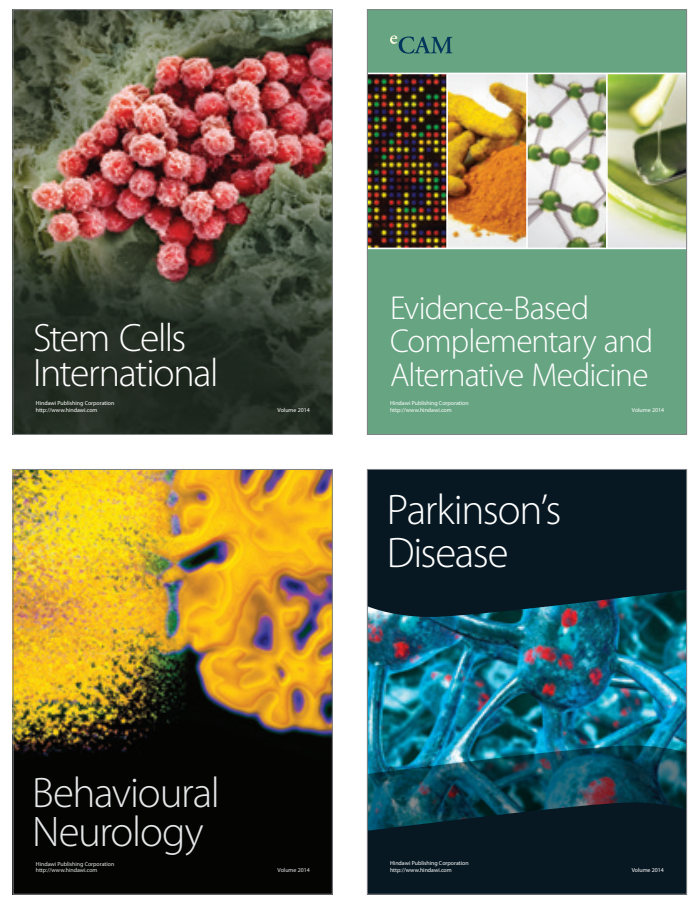
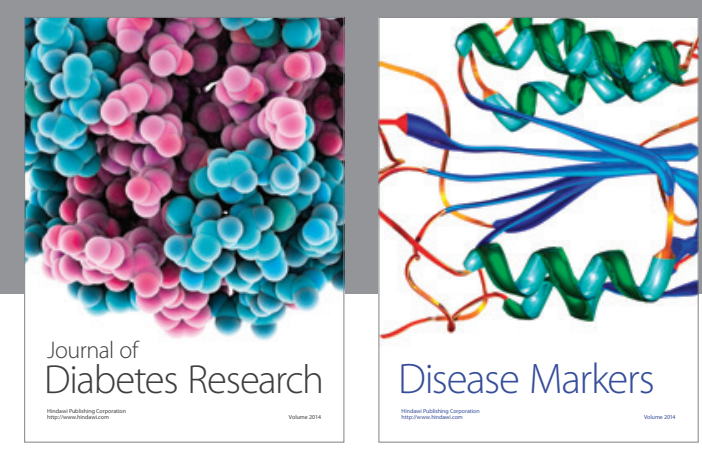

Disease Markers
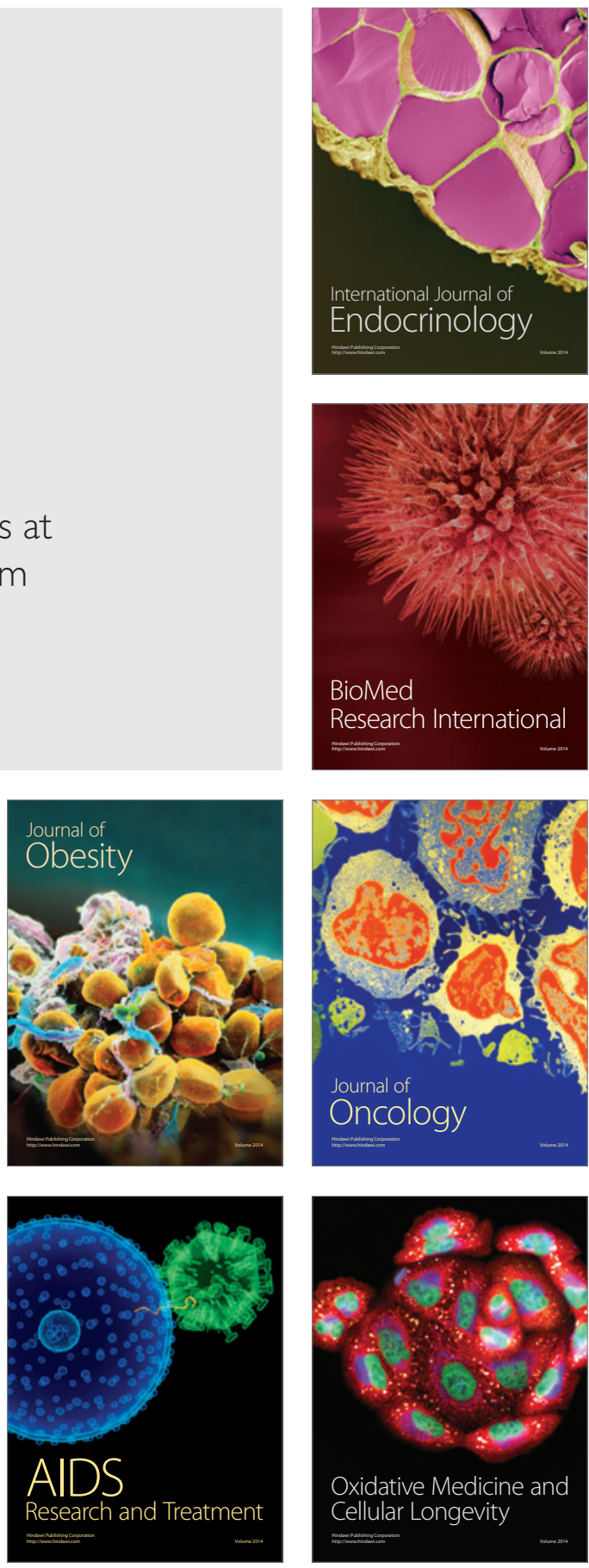